\title{
Kentsel Peyzajda Geleneksel Dokunun Sürdürülebilirliği: Bartın Örneği *
}

\author{
Sevgi GÖRMÜŞ ÇETINKALE ${ }^{1} \quad$ Sebahat AÇIKSÖZ ${ }^{1}$
}

Geliş Tarihi: 18.05.2006

\begin{abstract}
Öz: Kentlerin hızla büyümesi ile birlikte ortaya çıkan önemli sorunlardan biri, tarihi kimliklerini kaybetmesidir. Yeni yerleşim alanları geleneksel doku üzerinde baskı oluşturarak, bu yerleşim yerlerini düzensiz alanlara dönüştürmektedir. Bu dönüşüm Türkiye'de tarihî değerlere sahip kentlerin sorunudur. Yeni yerleşim alanlarının kent kimliğine saygılı olmadığı, her kentte aynı tip yapılaşma görüldüğü gözlenmektedir. Son yıllarda kentleşmenin hız kazandığı Bartın kenti, geleneksel dokusunu kaybetme sürecine girmiştir.Sivil mimarî örnekleri hızla azalmaya başlarken, tek tip yapılar kent dokusuna egemen olmaya başlamıştır. Bu çalışmada, Bartın kentinin yeni yerleşim alanları ile geleneksel yaşam çevresi arasındaki etkileşim incelenmekte; geleneksel dokuya ilişkin sosyal, kültürel ve fiziksel tipoloji analizi yapılmaktadır. Analiz sonuçları güncel gereksinimlerle karşılaştıııarak, geleneksel dokuya uyumlu yeni yerleşim modelleri oluşturulmasında dikkate alınması gereken plân kararlarının geliştirilmesi amaçlanmaktadır.
\end{abstract}

Anahtar Kelimeler: Kentsel kimlik, geleneksel doku, Bartın, tipolojik analiz, modern yerleşim tipleri

\section{Sustainability of Traditional Pattern in Urban Landscape: The Case of Bartın}

\begin{abstract}
One of the biggest problems, which emerge with the gaining momentum of urbanization, is the loss of identity of cities. New developed areas put pressure on traditional texture and turning them to the irregular areas. In Turkey, this alteration has been come to a common problem of cities that have historical value. It has been seen that new development have the same type of construction and has no respect to city identity. In recent years, the City of Bartın where urbanization has been increased, is in the process of losing its traditional texture. When architecture samples have been started decreasing, unplanned and carelessly done buildings have been started to be dominant on urban texture. In this study, the interaction between new settlement and traditional settlement has been examined; social, cultural and physical typology analyses have been done. The results of analysis compared with contemporary needs, development of plan decisions that reflect identity traditional texture have been aimed to form new settlement models.
\end{abstract}

Key Words: Urban identity, traditional pattern, Bartın, thypologic analysis, types of modern settlements

\section{Giriş}

Kentler zaman boyutu içinde algılanmaktadır. Kentin olumlu algılanmasında ise fiziksel düzen ve yapılaşma arasındaki genel uyum etkili olmaktadır. Kent kimliğinin belirlenmesinin yanı sıra, algılanmasına da katkıda bulunan bu fiziksel düzen, kentsel peyzaj olarak tanımlanmaktadır (Karaman 1991).

Kentsel peyzaj; tarihî çevre için önem kazanmakla birlikte, o yerin kimliğini anlamamızı sağlayan kavramlardan biridir. Bu kavram, kentsel çevre ile kimlik bütünlüğünü ve imge sürekliliğini içermektedir. Yeni kentsel gelişimlerin yerel değerlere saygılı olarak gelişmesi, imge sürekliliği açısından önem kazanmaktadır. Kentlerin fiziksel büyümeleriyle artan görsel kirlilik ya da genel ifadeyle, kentsel peyzajdaki bozulmalar nedeniyle kimlik, anlam ve imge yaratma kavramları günümüz kentsel tasarım çevrelerinin temel sorunları olmuştur (Karaman 1991).

$\mathrm{Bu}$ sorunların odak noktalarından biri, mevcut kentsel doku içine yapılacak uygulamaların çevreyle nasıl bir bütünlük sağlayacağının belirlenememesidir. Uygulamada çoğunlukla tasarımların kentin bütünlüğüne ve gelişmedeki sürekliliğine olumlu ya da olumsuz nasıl bir etkide bulunacağı önemsenmemektedir. 
Bu çalışmada, Bartın'ın kent dokusu ve önemli sorunlarından biri olan yeni yerleşim alanlarının bu doku içerisindeki uygunluğu incelenmektedir. Bartın kentinde gelişmekte olan yapılaşma, kentin tarihi sit alanları üzerinde olumsuz etkilere neden olmaktadır. Söz konusu olumsuz etkilerin, tarihi doku üzerindeki baskısını, yok etme tehlikesi yönünde sürdüreceği varsayılarak, koruma ve geliştirme bilinciyle var olan geleneksel dokunun, yapılaşmakta olan mekânlara yansıtılması çerçevesinde öneriler geliştirilmiştir.

\section{Materyal ve Yöntem}

Karadeniz Bölgesi'nin Batı Karadeniz Bölümü'nde bulunan Bartın, Karadeniz'den karayolu ile $13 \mathrm{~km}$ içeridedir. Kuzeyinde Karadeniz, güneydoğusunda Safranbolu ilçesi ile, güneyinde Karabük, doğusunda Kastamonu ve batısında Zonguldak illeri bulunmaktadır (Şekil 1).

Çalışma alanı Tarihi Kentsel Sit Alanı ile sınırlanmaktadır (Şekil 2).

Araştırmanın veri tarama işlemi, üniversite kütüphaneleri, halk kütüphaneleri, İller Bankası, Bartın Belediyesi, Çevre İl Müdürlüğü, Yerel gazeteler ve TMMOB Mimarlar Odası Bartın Şubesi'nde yapılmıştır. Yerel halkın ve Ill'de görev yapan fiziksel plancıların görüşleri alınmıştır

Araştırma alanının özgün dokusunu belirlemek için yararlanılan yazılı ve çizili materyal aşağıda belirtilmiştir:

- Topoğrafya haritası (1/25 000),

- Jeoloji haritası (1/10000),

- Bartın Çevre Düzeni Plânı (1/15000),

- Bartın Tarihi Kentsel Sit Alanı paftası (1/10000),

- Halihazır haritalar (20M I-C 1/1000),

- Bartın Nazım Plânı Tarihî Sit Dokusu (1/5000),

- Bartın Kentsel Sit-Etkileme Geçiş Alanı Koruma Amaçlı İmar Plânları (20M-IVa/20M-IVb/20MIIIa/20M-lc),

- Bartın-Kentsel Sit Alanı, Etkileme Geçiş Alanı Korunacak Sokaklar Koruma Amaçıı İmar Plânı Plân Koşulları Raporu.

Arazi çalışmaları sırasında, çekilen fotoğraflar, çizilen perspektifler, video çekimleri, yerel gazetelerin arşivleri, konut sakinlerinin eski fotoğrafları ve yere halk ile yapılan görüşmelerden yararlanılmıştır.

Araştırmanın Yöntemi: Araştırmada "kimlik kazandırma" ve "geleneksel dokunun sürekliliğini sağlayan yeni yerleşim modeli oluşturma" doğrultusunda örnek olarak seçilen Bartın Kentsel sit alanının yerleşim şekli, konut-bahçe-sokak tipolojileri kapsamında irdelenmiştir.

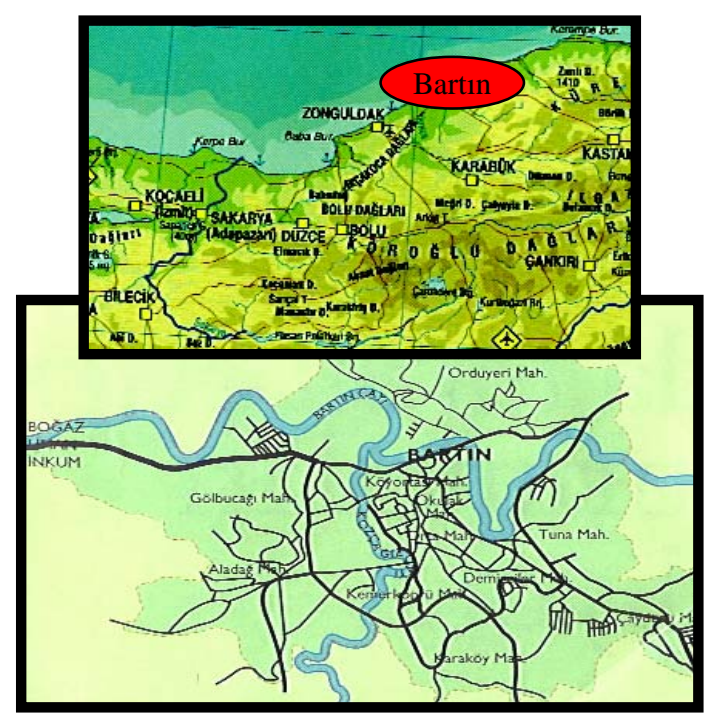

Şekil 1. Çalışma alanının bölgedeki yeri

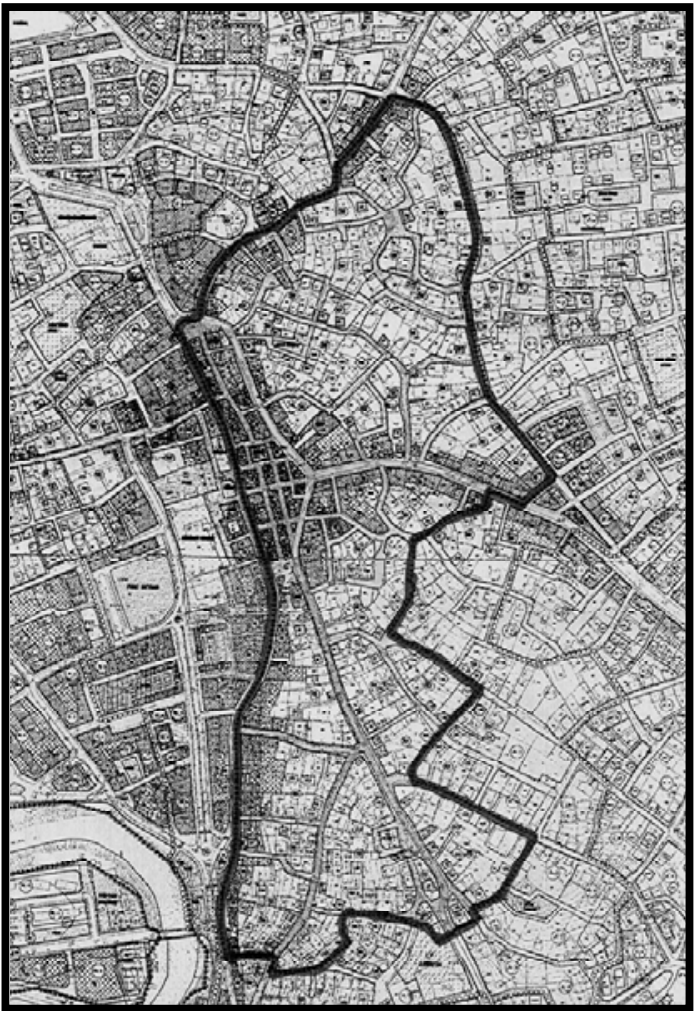

Şekil 2. Bartın tarihi kentsel sit alanı (Anonim 2002)

Araştırma bütününde seçilen alandaki geleneksel yerleşim dokusunun fiziksel, sosyal ve estetik mekân kimliği araştırılarak tipoloji geliştirilmiş, bu tipolojilere dayanarak geleneksel yerleşim dokusu ile uyumlu yeni yerleşim modeli için plân kararları oluşturulmuştur. 
Yeni yerleşmelerin tarihî değere sahip yerleşmeler ile uyumunun sağlanması, geleneksel yaşamdaki aktif sosyal yaşantının gelişen alanlara taşınması amacıyla yapılan çalışmada; Türel (1992)'in "Kentsel Tasarım Rehberleri” çalışmaları irdelenmiştir.

Tütengil (1975)'e göre bu yöntemin temel noktası; gelişme ve değişmeyi neden-sonuç ilişkileriyle birlikte ortaya koymak ve buna dayanarak yeni öneriler geliştirmektir (Arslan ve Ödekan, 1994).

Ayrıca kent araştırmalarında kullanılan "Kent Monografisi" konusu irdelenmiştir.

$\mathrm{Bu}$ incelemeler sonucunda araştırmaya ilişkin temel başlıklar aşağıda belirtilmiş, araştırmada izlenen yol Şekil 3'de verilmiştir.

\section{Bulgular ve Tartışma}

Bartın tarihî kent karakterini yansıtan çağdaş yerleşim alanlarına yönelik plan kararlarının geliştirilmesi için, çalışma alanına ilişkin doğal ve kültürel faktörler incelenmiştir. Bu kapsamda, tarihi kentsel sit alanının doğal çevre özellikleri, yerleşim tipolojisi ve gelişmekte olan alanların bu alanlar üzerindeki baskısı irdelenmiştir.

Konut tipolojisi :Konut tipolojisi konutların diziliş tiplerine ve bahçe ilişkisine göre irdelenmiştir.

Bartın evleri ahşap karkas olarak inşa edilmiştir. Su basman seviyesine kadar taştan olan yapıların yanı sıra; zemin katları tamamen taş olan yapılar görmek olasıdır. Ahşap dikme ve kirişlerin araları ahşap dolgu ile kapatılmış, üzeri bağdadi, rabitz veya ahşap kaplanmıştır (Kemik 1988)

Konutlar genellikle iki-üç katlıdır. Bartın evinde bir sofa ve bu sofa etrafında yer alan odaların oluşturduğu 10x10 m boyutunda taban alanına sahiptir. Konutta simetrik plan anlayışı egemendir. Konutlar; plân tiplerine, yapı düzenine, cephe elemanlarına ya da bulunduğu alana göre bahçeli ve sokakla sınırlı olarak farklı sınıflamalar kapsamında incelenebilir. Konut tipolojisi kapsamında konutlar, Deilmann ve ark. (1982)'un konut grupları çalışmaları dikkate alınarak; sıra, ikiz ve tek konutlar olarak sınıflandırılmıştır.

Sıra konutlar: Tanzimat Dönemi'nden sonra gelişen sıra konut özellikleri aşağıda sıralanmıştır:

- Sıra konutlar 4-6 birimden oluşmaktadır.

- Eğimli alanda yer almaktadır.
- Oturma odaları sokağa bakmaktadır.

- Ön cephesi sokakla sınırlıdır.

- Arka bahçe eğimlidir.

İkiz konutlar: Bartın'da ikiz konut kullanımı Tanzimat Dönemi'nde yaygınlaşmıştır (Şengerze 1998). Bu konutlar genellikle akrabalar tarafından kullanılmaktadır.

- İkiz konutların ön bahçeleri küçük, arka bahçeleri büyüktür.

- Birimlerin bahçeleri sınırlandırılmıştır

- Oturma odaları sokağa bakmaktadır.

- Ahşap çit kullanılarak sokaktan ayrılmıştır.

Tek konutlar: Bartın geleneksel dokusunun önemli bir bölümünü oluşturmaktadır. Genellikle bahçeli ve tek aile için planlanmış olan tek konutlar, günümüzde bölünerek, farklı aileler tarafından kullanılmaktadır. Tek konutların özellikleri aşağıda belirtilmiştir:

- Oturma mekânları sokağa bakmaktadır.

- Arka ve ön bahçeleri geniştir.

- Cephedeki mimarî öğelerin işçiliği ve özeni dikkat çekicidir.

Bahçe tipolojisi: Bahçe tipoljisi bahçenin konut ve komşu parselle olan ilişkisine göre irdelenmiştir.

Bartın geleneksel yerleşim dokusunun önemli bir özelliği geniş bahçelere sahip olmasıdır. Sokaktan eve geçiş bahçe aracılığıyla sağlanmıştır. Bahçeler sokaktan yöre ağzı ile "daraba" olarak ifade edilen çit elemanı ile ayrılmıştır. Hemen hemen her bahçede kuyu bulunmaktadır. Ayrıca her mahallede bir ya da iki tane evin bahçesinde dibek taşı bulunmaktadır. Yürüme alanları kayrak taşlarıyla döşenmiştir. Bartın İli geleneksel yerleşim dokusunda bahçenin sokakla ilişkisi güçlü olmakla beraber, özgür ve sade bir yaşam tarzı sunmaktadır (Kemik 1988, Çilsüleymanoğlu 1996).

Geleneksel yerleşim alanındaki bahçeleri, konutların düzenine göre, yan yana bahçeler ve sırt sırta bahçeler; konuta ait olan bahçeyi ise ön, arka ve yan bahçe olarak sınıflandırmak mümkündür.

Ön bahçe; zemini genellikle kayrak taşı ile döşenmiştir. Arka bahçeye göre sınırları dar tutulmuş, süs bitkileri kullanılmıştır. Kullanılan bitkileri aşağıdaki şekilde sıralamak olasıdır:

- Mevsimlik Çiçekler,

- Yerörtücü bitkiler,

- Sarılıcı bitkiler,

- Geniş yapraklı ve iğne yapraklı ağaçlar. 


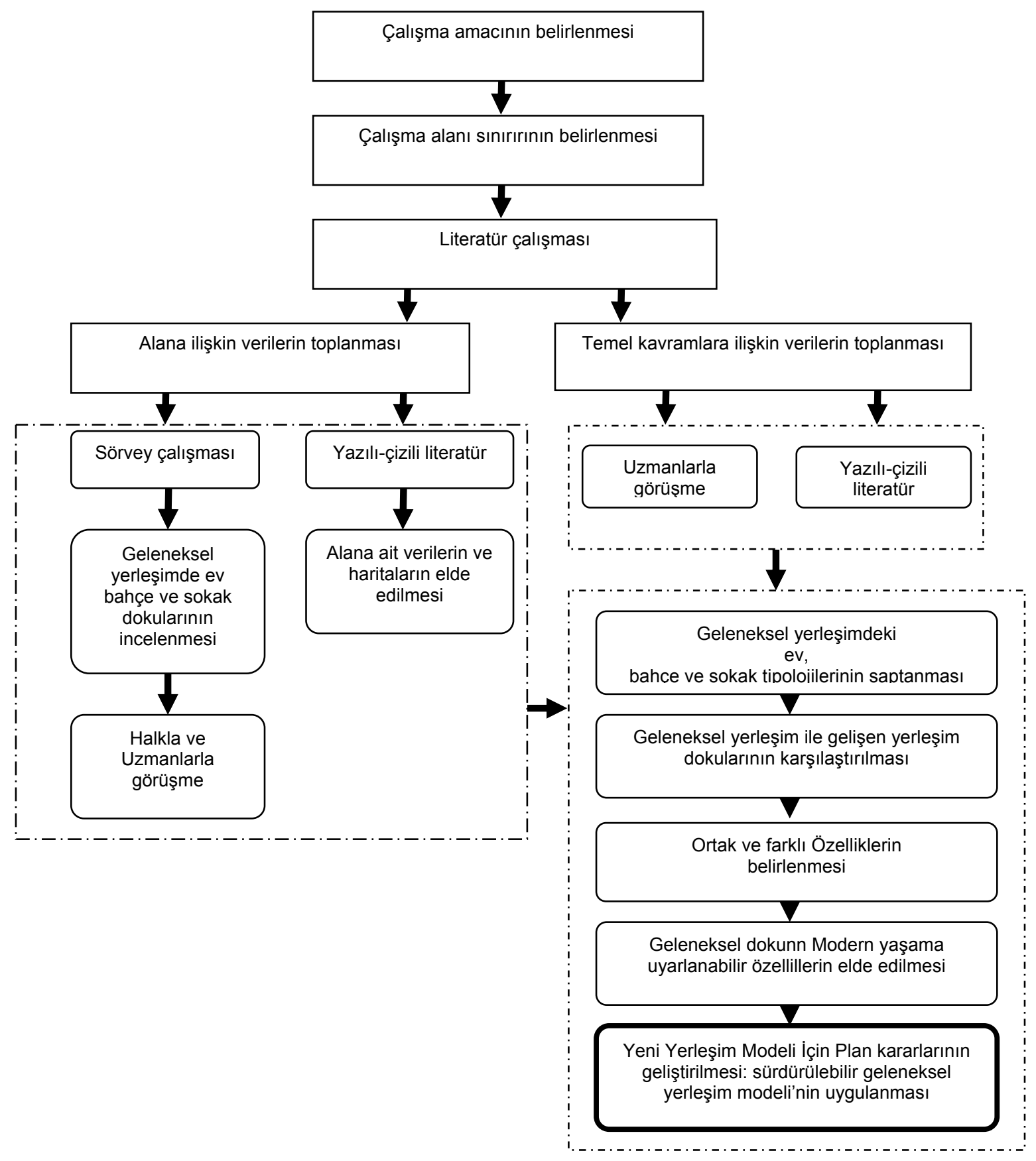

Şekil 3. Araştırmada izlenen yol 
Arka bahçe: Ev halkının geçimine katkıda bulunacak şekilde tasarlanmıştır. Bu nedenle geniş bir alanı kaplamaktadır. Ev halkı işlerinin tamamını arka bahçede yapmaktadır. Yapılan işin amacına, aile gelir durumuna ve ailenin konumuna göre arka bahçedeki mekânlar farklılık göstermektedir. Bu mekânlar oturma alanı, çamaşır hâne, ocak, kuyu, depo, kümes ve ahır şeklinde sıralanmaktadır:

Yan bahçe: Komşu yapı ya da sokak ile olan boşluğu ifade etmektedir. Bartın evlerinin bir kısmında yan bahçe bulunmaktadır. Bazı konutlarda konut girişi ya da arka bahçe girişi yan bahçeden sağlanmaktadır. Genellikle "kiler" olarak kullanılan ahşap iskelet üzerindeki yapı yan bahçede yer almaktadır.

Sokak tipolojisi: Sokakların sınıflandırılmasında yönlendirme ve arazinin kullanım şekli dikkate alınmıştır. Bartın sokağı sahip olduğu donatılar nedeniyle, sosyal bir mekân işlevi görmektedir. Konutlar büyük bahçelere sahip olduğu halde buluşma noktası olarak sokağın daha çok tercih edilmesinin nedenlerinden birinin çeşme olduğu varsayılabilir. Bunun yanısıra, konutun oturma mekânının sokağa bakması, bu hareketlenmeyi canlandıran etmenlerden biridir. Bartın tarihî sokakları genellikle dar olmakla birlikte, çizgi olarak belirli bir ritmi ve uyumu izlemektedir. Sokaklar orantılı bir düzene sahip olmalarının yanında, ön bahçelerde yaratılan bitkisel tasarımlarla bütünlük kazandırılmıştır. Sokağın organik yapıya sahip olması, sürpriz mekânların oluşmasına neden olmuştur. Örneğin; dar ve kırık bir sokak bir meydana bağlanarak, ferahlık duygusu yaratılmıştır. Bütün sokak tiplerinde çitler, çıkmalar, merdivenler, çeşmeler, döşeme gibi öğeler görülmektedir.

Sokak tipolojisindeki sokak sınıflandırması, Raverdy ve Raverdy (2003)'ün çalışması doğrultusunda gerçekleştirilmiştir. Bartın geleneksel yerleşim dokusunun izlerini taşıyan sokaklar bu çalışma çerçevesinde irdelenerek sınıflandırma aşağıda sunulmuştur:

- Eğimli sokaklar (Şekil 4),

- Düz sokaklar (Şekil 5),

- Merdivenli sokaklar (Şekil 6),

- Kırık sokaklar (Şekil 7),

- Çıkmaz sokaklar (Şekil 8).

Bartın'da gelişen alanların geleneksel konut dokusuna etkileri: Araştırmanın bu bölümünde Bartın'daki plânsız gelişmenin Tarihi kentsel sit dokusu üzerinde oluşturduğu baskı irdelenmiş, bu baskıların oluşumuna neden olan güncel gereksinimler model oluşumunda dikkate alınmıştır.

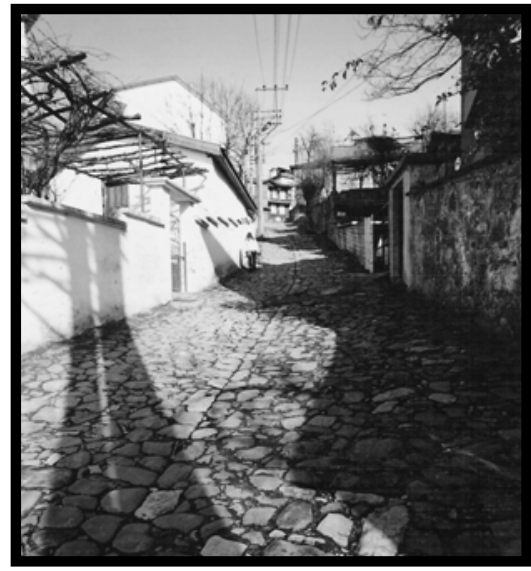

Şekil 4. Eğimli sokak örneği

(Atlama Sokak)

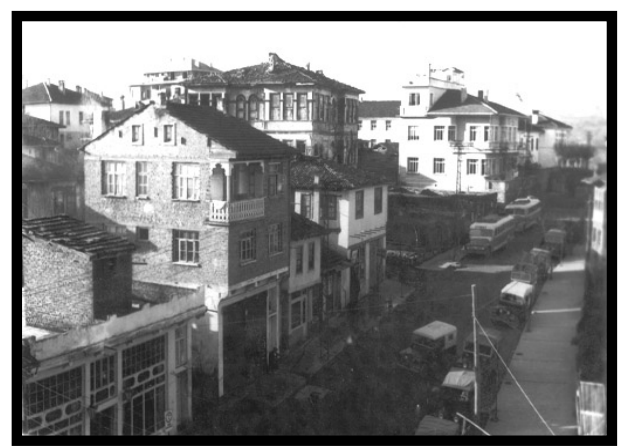

Şekil 5. Düz Sokak Örneği(Anonim, 2006a) (Hükümet Caddesi)

Bartın kentinin çeşitli etkiler altında sürekli olarak değiş̧iği gözlenmektedir. Bir yandan tarihî dokuya sahip alanlar inmâl nedeniyle yok olurken; diğer yandan gelişen yerleşim alanları sosyal mekânlar, kentsel donatılar vb. açılardan yetersiz kalmakta ve kimliksiz karakteriyle kentsel dokuya egemen olmaktadır. Bartın da korunması gerekli 674 sivil mimari örneğin sayısının son tescil çalışmaklarına göre 207' ye düştüğü görülmektedir (Özcan 2002).

1935 tarihli Bartın kent siluetinde sivil mimarî örneklerinin yoğunlaştığı ve geleneksel mekândaki kapalı ve açık alan oranlarının birbirine yakın olduğu görülmektedir. Ancak günümüzdeki kent silueti incelendiğinde, çarpık ve hızı kentleşme sonucu ortaya çıkmış tek tip yapılaşma göze çarpmaktadır. Kent dokusunun değişimini yansıtan, kentin önemli imaj noktaları (camiler, konutlar) kent siluetinden silinmiştir. 


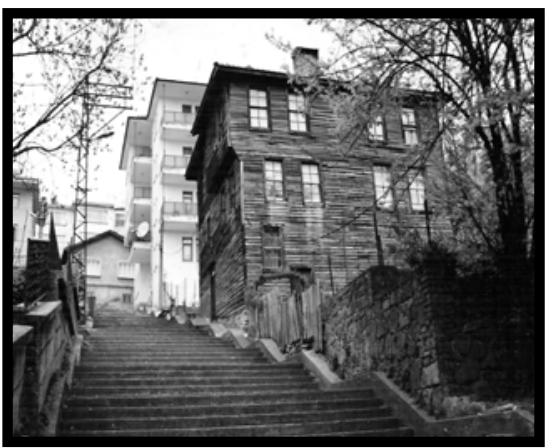

Şekil 6. Merdivenli sokak örneği (Toscuoălu Sokaăı)

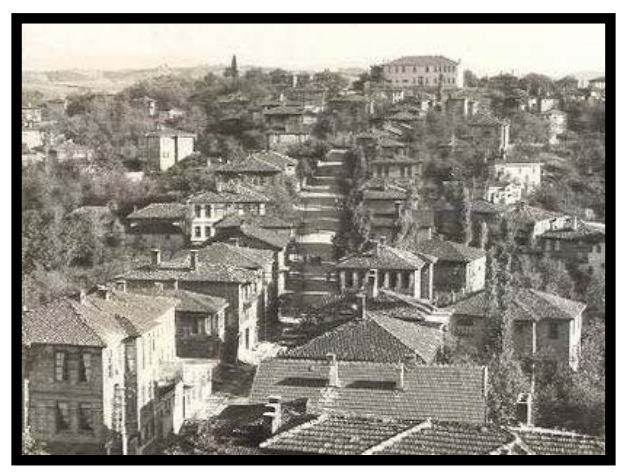

Şekil 7. Kırık sokak örneği (Anonim, 2006b) (Aşaği Cami Caddesi)

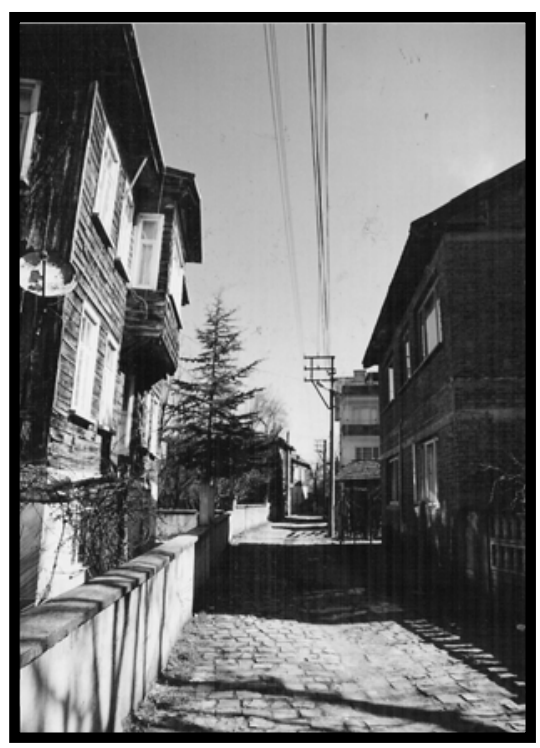

Şekil 8. Çıkmaz sokak (1 Nolu Kavaklı Sokağı)

\section{Sonuç ve Öneriler}

Günümüzde Yaşanabilecek bir çevreden çok, yaşanacak kadar bir konut ve çevresi mantığının egemen olduğu görülmektedir. Bu anlayışın varolduğu kentlerden biri durumunda olan Bartın'da geleneksel yaşam örgüsü bir bütün olarak korunamamaktadır.

Bartın kent sakinlerinin geleneksel yaşama bağlılığı kültürel anlamda devam ederken; fiziksel anlamda bu devamlıı̆̆ın sağlanamadığı saptanmıştır. $\mathrm{Bu}$ ikilemin ve yeni yerleşim alanlarının Bartın geleneksel kent dokusunda oluşturduğu etkilerin sonuçları aşağıdaki gibi yorumlanabilir:

- Kentsel çevre kalitesinin azalması (fiziksel ve kültürel anlamda),

- Yeşil alanların azalması

- Görsel kirlilik,

- Gürültü kirliliği,

-Alt yapı sorunları.

Geleneksel dokuya sahip ve geleneksel yaşama olan bağlıığın devam ettiği kentlerde bu tür sorunların yaşanmaması ya da giderilmesi için geleneksel yaşamın kültürel ve fiziksel sürdürülebilirliği sağlanmalıdır. Bu çerçevede çalışmada sürdürülebilir geleneksel yerleşim modeli önerilmiştir (Şekil 9) .

Sürdürülebilir geleneksel yerleşim modelinde alana ve geleneksel yaşama ilişkin bileşenler irdelenip, geleneksel ve modern yaşamın uyuşan özellikleri saptanmıştır.

- $\mathrm{Bu}$ model geleneksel yerleşimin sürdürülebilirliğini doğal, fiziksel ve kültürel etmenlerin yanısıra; kent kültürünün değişim yönü ve nedenlerini irdelemektedir.

-Değişim önlenemez bir olgu olduğu kabul edilerek modelin değişime açık olması gerektiği düşünülmüştür.

-Modelin farklı yerleşim birimlerine uygulanmasında her yerin kendine özgün yapısı olduğundan farklı sonuçlar elde edileceği düşünülmektedir. Sözkonusu sonuçlara ulaşmak için model genişletilebilir.

Modelin çalışma alanı olan Bartın kentine uygulanması sonucunda ulaşılan planlama ilkeleri için dikkate alınması gereken etmenler şunlardır:

•Kültürel etmenlerin yanı sıra fiziksel (iklim, hidroloji, jeoloji, topografya) ve yapay etmenler (doğal alanla uyumlu düzenli çevre), 


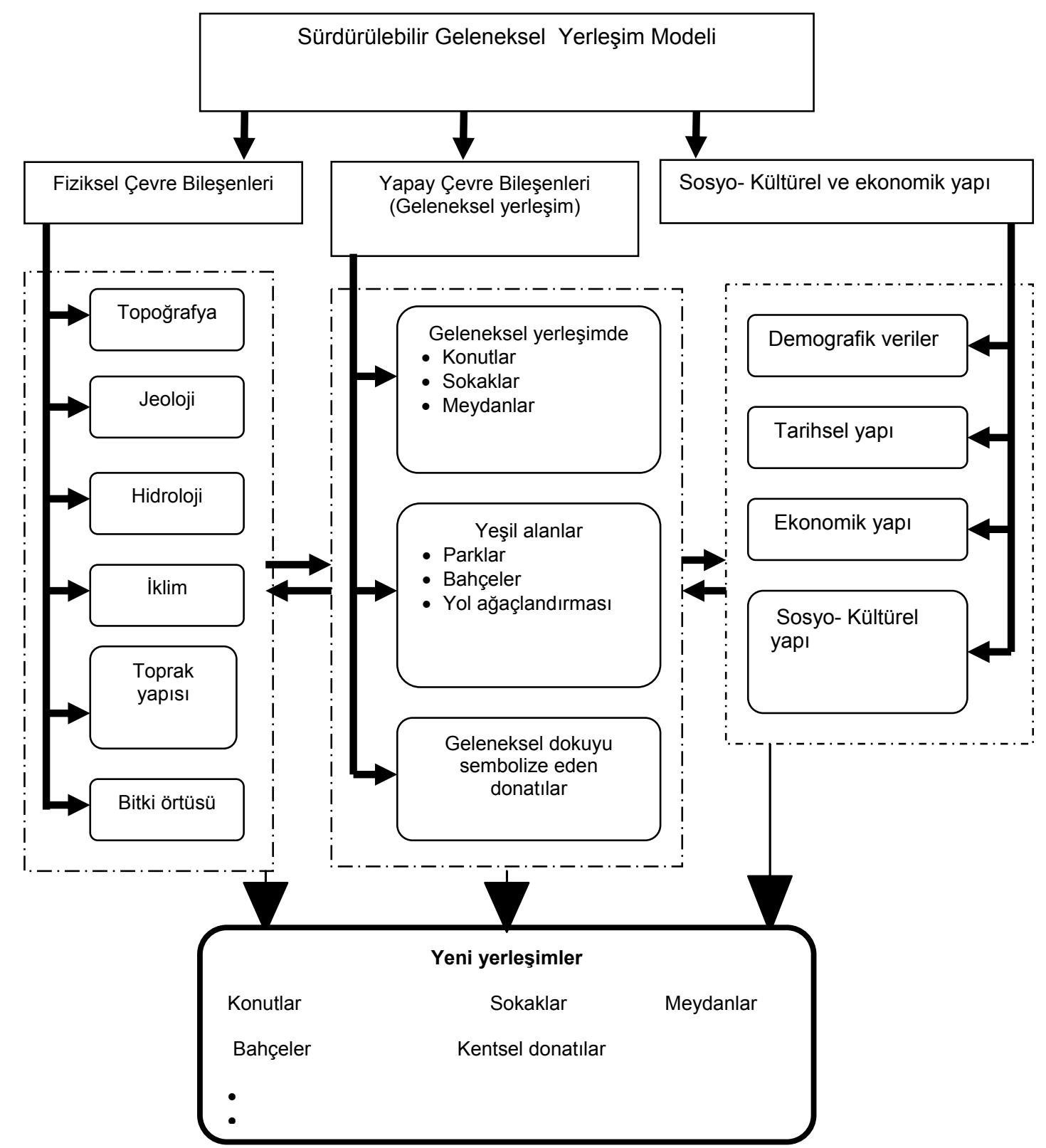

Şekil 9. Sürdürülebilir Geleneksel Yerleşim Modeli

- Bartın kent nüfusundaki artış ve nedenleri (2000 yılı nüfus verilerine göre),

- Geleneksel yaşam örgüsü vegüncel yaşam yaşam biçimi.

Bartın kentsel kimliğin ve imgenin devamlılığı için gelişmekte olan alanların, geleneksel doku temel alınarak tasarlanması dikate alınması gereken ve plan kararlarının şunlardır:

- Çok katlı yapılaşmanın önlenmesi ( yapılaşmanın insan ölçeğine uyumlu olması),

- Ayrık düzende konutlar (bahçeli bireysel evlerin teşvik edilmesi), 
- Yayalaştırma ve yaya öncelikli ulaşım sirkülasyonu,

- Yeni yapılara Bartın geleneksel konut özelliğinin yansıtılması,

- Sosyal mekânlar,

- Konut-bahçe-sokak mekânları arasında güçlü bağlantıların kurulması,

- Geleneksel yerleşim donatılarının özgün yapısını yansıtan donatı elemanları,

- Konut sahibinin sosyo-ekonomik ve kültürel yapısı doğrultusunda bahçe kullanımı,

- Kentsel tarım olanaklarının sağlanması.

Son söz olarak, görünümünde çeşitli detaylar barındıran Bartın geleneksel yerleşim dokusu yok olmaktadır. Oysa birlik ve çeşitliliğin uyumu yaşama ve mekâna anlam kazandırmakta ve birbirini tamamlamaktadır. Bartın geleneksel yerleşim dokusu da günümüz fiziksel, sosyal, kültürel ve ekonomik koşullarına uyumlu hale getirilirse, kentin tarihî karakterinin sürdürülebilirliği sağlanmış olacaktır. Geleneksel yerleşim dokusunun özgünlüğünü güncel gereksinimler doğrultusunda yeniden yorumlamak bulunduğumuz dönemin kimliğini geleceğe aktarması açısından oldukça önemlidir.

\section{Kaynaklar}

Anonim. 1978. Analitik Etüdler, Bartın. İller Bankası Raporu, Ankara.

Anonim. 2002. İmar Haritaları, Bartın Belediyesi İmar İşleri, Bartın.

Anonim. 2006a. Eskiler ve Bartın Tarihi. http://www.bartin74.net/sayfalar/eskilerden.asp

$$
(1.10 .2006)
$$

Anonim (2006b) Eskiler ve Bartın Tarih http://www.bartin74.net/sayfalar/eskilerden.asp
Arslan, R. ve A. Ödekan. 1994 Araştırma Yöntemleri, Yıldız Teknik Üniversitesi Mimarlık Fakültesi Şehir Bölge Plânlama Bölümü Yayını, İstanbul.

Çilsüleymanoğlu, S. 1996. Bartın Halk Kültürü, I.Cilt. Araştırma-Derleme-İnceleme, Türk Tarih Kurumu Basımevi, Ankara.

Deilmann, H., G. Bickenbach and H. Pfeiffer. 1982. Konut Grupları, Housing Groups, Zones d'Habitat, Ayıntap Yayıncılık, Ankara.

Karaman, A. 1991. Kentsel Peyzaj İçinde Yüksek Yapı Tasarım İlkeleri: İstanbul Üzerinde Gözlemler, Ders Notları, Mimar Sinan Üniv., Mimarlık Fak., İstanbul.

Kemik, C. 1988. Bartın Kentsel Değerler ve Sivil Mimarî Örnekleri, Yüksek Lisans Tezi, Yıldız Teknik Üniv., İstanbul.

Raverdy, S. and X. B. Raverdy. 2003. Evler-Mevsimler. Paris Ankara Yürüyüşü Boyunca Gözlemlenen Yerel Mimarlıklar, Çeviren: Alp Tümertekin, Yapı Kredi Yayını, İstanbul.

Şengerze, K. 1998. Tanzimat Modernleşmesi Sürecinde Bartın Evleri, Yüksek Lisans Tezi, İstanbul Teknik Üniversitesi Fen Bilimleri Enstitüsü, İstanbul.

Türel, G. D. 1992. Kentsel Tasarım Sorunları, Süreci ve Tasarım Yönlendirici Projelerin Sürece Katılımı. II.Kentsel Tasarım ve Uygulamalar Sempozyumu, Mimar Sinan Üniv. Mimarlık Fak. Şehir Bölge Plânlama Bölümü Yayını, İstanbul.

Özcan, Ü. 2002. Bartın Sürdürülebilir Kalkınma Planı II. Aşama: Eylem Planı Temel Ekonomik ve İnsani Kalkınma Stratejileri. Bartın Belediyesi, Bartın.

Illetişim adresi:

Sebahat AÇIKSÖZ

Zonguldak Karaelmas Üniv.

Bartın Orman Fak. Peyzaj Mimarlığı Bölümü- Bartın 